Chulieieva 0.,
Zolotaryov V.

\title{
EFFECT OF THE MODIFIER ON THE THERMOPHYSICAL PROPERTIES OF FIREPROOF ETHYLENE-VINYL ACETATE COPOLYMER COMPOSITION MATERIALS
}

Об’єктом дослідження є теплофізичні процеси пожежобезпечних композиційних матеріалів кополімеру етилену з вінілацетатом, до складу яких входять наповнювачі-антипірени та модифікатор. 3 метою забезпечення показників негорючості полімерні композицї мають високий ступень наповнення до $60 \%$ мас. Використовували полімерну матрицю - кополімер етилену з вінілацетатом. Неорганічні наповнювачі-антипірени - тригідрат оксиду алюмінію з середнім діаметром часточок 1,5 мкм та 3,0 мкм, дигідрат оксиду магнію з середнім діаметром часточок 3,0 мкм та 3,7 мкм та гідромагнезит з середнім діаметром часточок 1,4 мкм. Одним з найбільш проблемних місць є процес переробки таких композицій.

В ході дослідження використовували модифікатор аміносилан. Використовуючи метод термогравіметричного аналізу та диференційної скануючої калориметрї TGA/DSC, визначено температури плавлення та розкладу, ступень кристалічності, питому теплоємність, втрату маси.

Отримані результати показують, що температури плавлення знижуються з підвищенням вмісту модифікатора для всіх зразків. Суттєве зниження температури плавлення спостерігається за умови використання наповнювачів з більшим середнім діаметром часточок. Температура початку розкладу збільшується для всіх полімерних композицій, до яких введено модифікатор. Ступінь кристалічності збільшується зі зростанням вмісту модифікатора полімерних композицій. Питома теплоємність всіх полімерних композищій підвищується зі збільшенням кількості модифікатора. Це пов'язано з впливом наповнювачів-антипіренів та модифікатору на формування структури полімерних композицій.

Завдяки иьому забезпечується можливість зниження температури плавлення на 1,2-16,2 градусів в залежності від хімічного складу та дисперсності наповнювачів антипіренів в присутності модифікатору. Збільшується ступень кристалічності та підвищується питома теплоємність зі збільшенням вмісту модифікатору. Значно підвищуються від 20 до 45 градусів температури початку розкладу полімерних композицій.

Отримані результати будуть корисними під час розробки пожежобезпечних рецептур полімерних композицій для кабельної продукиї, враховуючи їх теплофізичні показники.

Ключові слова: композиційні матеріали, вплив модифікатора, кополімер етилену з вінілацетатом, наповнювачі-антипірени, теплофізичні властивості.

\section{Introduction}

In modern cable production, polymer composite materials are widely used [1]. In recent years, technical requirements for cable products have increased and, as a result, the need to develop new advanced materials, including fireproof polymer composite materials. Composite fireproof materials of polyolefins are very promising. This is due to the growing use of wires and cables for the energy industry, nuclear energy, railway transport, construction, etc. In these industries, the requirements for cable materials for fire safety are much higher than for generalpurpose cables. Insulation and sheathing materials must comply with European standards. It is necessary to create special-purpose materials that meet specific operational needs - not the spread of combustion and the absence of halogens in the composition of the material, reduction of smoke and the toxicity of combustion products.

The creation of halogen-free formulations is achieved by introducing flame retardants - metal hydroxides into the base polymer. Aluminum hydroxides $\mathrm{Al}(\mathrm{OH})_{3}$ and magnesium $\mathrm{Mg}(\mathrm{OH})_{2}$ of synthetic and natural origin, hydro- magnesites, have been used commercially. Processing of such materials causes difficulties, due to the high content of fillers, flame retardants. A modifier is used to regulate the rheological properties of polymer compositions [2].

Polymer composite materials during processing and operation are exposed to elevated temperatures. And during combustion, the endothermic reaction degrades with the release of water, carbon oxides and metal oxides.

Therefore, the study of the dependence of thermophysical properties on the composition of the polymer composition, taking into account the modifier, the chemical composition, the dispersion of fillers, flame retardants is an actual problem.

\section{The object of research and its technological audit}

The object of research is the thermophysical processes of fireproof composite materials: ethylene-vinyl acetate copolymer, which contains fire retardant fillers and a modifier. In order to ensure the incombustibility performance, polymer compositions have a high degree of filling up to 
$60 \%$ by mass. Polymer matrix is used (a copolymer of ethylene with vinyl acetate). Inorganic fillers-flame retardants are aluminum oxide trihydrate, magnesium oxide dihydrate and hydromagnesite.

One of the most problematic places is the process of processing such compositions. The introduction of fire retardant fillers into the polymer matrix reduces the crystallinity degree, specific heat and decomposition temperatures of polymer compositions. To improve these indicators, aminosilane is injected into the polymer composition as a modifier.

\section{The aim and objectives of research}

The aim of research is studying the change in the thermophysical properties of fireproof composite materials, ethylene copolymer with vinyl acetate, depending on the concentration of the modifier and the dispersity of the flame retardant fillers. This will allow a reasonable approach to determining the type of polymer, modifier, type and dispersion of the flame retardant filler. It also allows to quickly adjust the formulation of the composition depending on the available raw materials or the desired thermal properties of the final product.

To achieve this aim it is necessary to perform the following objectives:

1. To investigate the dependence of the temperature of physical transformations (melting point), the crystallinity degree of the specific heat on the amount of modifier and the properties of the ingredients of the polymer compositions.

2. To investigate the dependence of the start temperature of decomposition and mass loss on the amount of modifier and the properties of the ingredients of the polymer compositions.

\section{Research of existing solutions of the problem}

Analysis of the literature data shows that one of the means of reducing the flammability of polymeric materials of polyolefins is the introduction of flame retardants into the polymer composition [3]. For this purpose, inorganic fillers-flame retardants are used. In the real fire conditions of PVC (polyvinyl chloride), plastic compounds, which are elements of cables having an oxygen index (OI) value of up to 40 units, are a source of release of corrosive $\mathrm{HCl}$ gases and significant smoke. Therefore, in order to solve the problems associated with the release of $\mathrm{HCl}$ and smoke, polymer compositions were created that do not emit corrosive gases and have a much lower level of smoke emission [4]. These materials not only increase the fire resistance due to the absorption of a larger amount of heat, but also neutralize acid gases, which leads to a decrease in smoke generation [5]. Polyolefins are usually used as the polymer base, and aluminum oxide trihydrate, magnesium oxide dihydrate, and magnesites are used as flame retardants. This direction is dedicated to a significant amount of research. The mechanical and fire-resistant properties of the composite materials of kev and aluminum oxide trihydrate with different particle diameters were studied, and the change in these properties depending on the dispersity of the filler was determined [6]. The effectiveness of the use of calcium hydroxide with the aim of improving the fire resistance of medium density polyethylene is shown [7]. The refractory properties of composite materials are studied. The base polymer in them is LDPE/EVA. Metal hydroxides (magnesium hydroxide and aluminum oxide trihydrate) were used as fillers for flame retardants. Refractory properties were assessed by horizontal combustion and oxygen index [8]. TGA/DSC methods were used to study polymer compositions using magnesium dioxin as a flame retardant. The heat capacity of these materials was determined [9].

The fire resistance of a copolymer of ethylene with vinyl acetate, which was filled with metal hydroxides (alumina trihydrate and magnesium oxide dihydrate) and silicon dioxide, was investigated. It was noted that silica provides an advantage if the amount and other properties of fillers contribute to the formation of a protective mineral layer [10].

It has been established that in order to ensure the fire-safe properties of composite materials for insulation and cable sheaths and better safety of electrical equipment and devices, there should be a very high degree of filling of the polymer matrix with metal hydrates. This can lead to loss of flexibility and low mechanical properties with simultaneous processing problems [11].

The possibility of using magnesium hydroxide, zinc borates, and their joint action are studied as an inhibitor of combustion of polypropylene fiber. The efficiency of using zinc borate is shown. The use of magnesium hydroxide is ineffective. Thermal, mechanical and morphological properties were tested [12].

The efficiency of using amino alkoxysilane as a coupling agent [13] to improve polymer-filler contacts in composite materials and process inorganic substrates to increase the adhesion of various polymers and coatings $[14,15]$ has been shown.

Information on the use of amino alkoxysilane to modify fireproof polymer compositions, including those based on ethylene-vinyl acetate copolymers, is practically absent in the literature.

These studies show that the properties of polymer compositions vary depending on the composition. During the processing of polymer compositions and during the operation of cables, melting points and decompositions are important. However, many issues related to the creation of fireproof polymer compositions are still insufficiently studied. This is especially true of the effect of the modifier, fillers-flame retardants and the polymer matrix on thermal properties.

\section{Methods of research}

Ethylene vinyl acetate copolymer (EVA) is investigated, the characteristics of which are given in Table 1, as well as filler-flame retardants, which used alumina trihydrate, magnesium oxide dihydrate, a mixture of magnesite and hydromagnesite.

Table 1

EVA characteristics

\begin{tabular}{|l|c|}
\hline \multicolumn{1}{|c|}{ Indicator } & EVA \\
\hline Density, $\mathrm{kg} / \mathrm{m}^{3}$ & 951 \\
\hline Melt flow rate, $2.16 \mathrm{~kg}, \mathrm{~g} / 10 \mathrm{~min}$ & 5 \\
\hline Vinyl acetate content, \% & 28 \\
\hline
\end{tabular}

Characteristics of fillers-fire retardants are given in Table 2. The modifier is aminosilane (N-(3-trimethoxysilane) propylbutylamine). Characteristics are given in Table 3. 
Characteristics of fire retardant fillers

Table 2

\begin{tabular}{|c|c|c|c|c|c|}
\hline \multirow{2}{*}{ Indicator } & \multicolumn{2}{|c|}{$\mathrm{Al}(\mathrm{OH})_{3}$} & \multicolumn{2}{|c|}{$\mathrm{Mg}(\mathrm{OH})_{2}$} & \multirow{2}{*}{$\begin{array}{c}\mathrm{Mg}_{5}\left(\mathrm{CO}_{3}\right)_{4}(\mathrm{OH})_{2} \cdot 4 \mathrm{H}_{2} \mathrm{O} ; \\
\mathrm{Mg}_{3} \mathrm{Ca}\left(\mathrm{CO}_{3}\right)_{4} \\
\text { Sample } \\
\text { No.5 }\end{array}$} \\
\hline & $\begin{array}{c}\text { Sample } \\
\text { No. } 1\end{array}$ & $\begin{array}{c}\text { Sample } \\
\text { No.2 }\end{array}$ & $\begin{array}{c}\text { Sample } \\
\text { No.3 }\end{array}$ & $\begin{array}{c}\text { Sample } \\
\text { No. } 4\end{array}$ & \\
\hline $\begin{array}{l}\text { Mass } \\
\text { fraction, \%: } \\
\text { - } \mathrm{Mg}(\mathrm{OH})_{2} ; \\
-\mathrm{Al}(\mathrm{OH})_{3} ; \\
-\mathrm{SiO}_{2} ; \\
-\mathrm{Fe}_{2} \mathrm{O}_{3} ; \\
-\mathrm{Na}_{2} \mathrm{O} ; \\
-\mathrm{CaO}\end{array}$ & $\begin{array}{c}- \\
>99.2 \\
<0.05 \\
<0.035 \\
<0.6 \\
-\end{array}$ & $\begin{array}{c}- \\
>99.5 \\
<0.1 \\
<0.03 \\
<0.4 \\
-\end{array}$ & $\begin{array}{c}>93 \\
- \\
<0.05 \\
<0.3 \\
<0.05 \\
-\end{array}$ & $\begin{array}{c}>93.2 \\
- \\
2.2 \pm 0.2 \\
0.12 \pm 0.02 \\
- \\
2.2 \pm 0.2\end{array}$ & $\begin{array}{c}98.96 \\
- \\
0.67 \\
0.04 \\
<0.05 \\
-\end{array}$ \\
\hline $\begin{array}{l}\text { Median particle } \\
\text { diameter, mic- } \\
\text { rons: } \\
\text { - average }\left(D_{50}\right) ; \\
\text { - } \max \left(D_{98}\right) ; \\
\text { - } \min \left(D_{10}\right)\end{array}$ & $\begin{array}{l}1.5 \\
3.6 \\
0.5\end{array}$ & $\begin{array}{c}3 \\
18 \\
1\end{array}$ & $\begin{array}{c}3 \\
20 \\
1\end{array}$ & $\begin{array}{c}3.7 \\
12.5 \\
1.1\end{array}$ & $\begin{array}{c}1.4 \\
8.35 \\
1.02\end{array}$ \\
\hline
\end{tabular}

Table 3

Characteristics of aminosilane

\begin{tabular}{|l|c|}
\hline \multicolumn{1}{|c|}{ Indicator } & Value \\
\hline Density, $\mathrm{kg} / \mathrm{m}^{3}, 20^{\circ} \mathrm{C}$ & 947 \\
\hline Dynamic viscosity, $\mathrm{mPa} \cdot \mathrm{s}, 20^{\circ} \mathrm{C}$ & 2.5 \\
\hline Boiling temperature, ${ }^{\circ} \mathrm{C}$ & 260 \\
\hline
\end{tabular}

The ingredients of the polymer compositions are weighed on the scales with an accuracy of $0.001 \mathrm{~g}$ and sequentially loaded onto the rollers. Temperature of the work

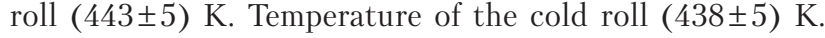
Samples of roll rollers 3 minutes at a gap of $0.4-0.5 \mathrm{~mm}$. Then the gap was adjusted to $2 \mathrm{~mm}$. In the process of rolling periodically cut at least 2 times per minute. Last minute rolls without undercuts.

Samples are conditioned at a temperature of (293 \pm 2$) \mathrm{K}$ for at least 24 hours.

Rollers have a friction of 1.5 .

A series of experiments on the study of phase transitions, thermo-oxidative degradation processes was carried out using a thermogravimetric analysis device and TGA/DSC 1/1100 SF and DSC 1 differential scanning calorimetry (Switzerland) at $293 \mathrm{~K}$ to $743 \mathrm{~K}$ and a heating rate of 10 degrees/min.

Differential scanning calorimetry is based on the wellknown Boersma principle, or the principle of heat flow, according to which the heat fluxes of a sample are compared to a control measurement.

TGA/DSC 1 is a highly sensitive measuring instrument for thermogravimetric analysis (TGA). The main element of the TGA/DSC 1 is a measuring cell consisting of a furnace and a scale. In addition to the mass of the sample, which is measured using the built-in highly sensitive scales, TGA/DSC 1 provides a measurement of the temperature of the sample. Together with the value of the reference temperature, these values form the basis of the thermogravimetric analysis of the sample. In addition, TGA/DSC 1 allows to measure the heat flux signal, which ensures the use of differential scanning calorimetry (DSC). The temperature of the sample and the heat flux signal are determined by the indicators of temperature sensors, measured directly with a thermocouple installed in the crucible holder.
The heat flux is calculated from the differential thermal analysis (DTA) signal, which is the difference between the sample temperature and the temperature value, which is specified in the temperature program. The measurement value of the module transmits software that calculates the value of the heat flux, based on the formulas:

$$
\begin{aligned}
& \varphi=E_{(T)} S D T A, \\
& S D T A=T_{s}-T_{\text {set }},
\end{aligned}
$$

where $\varphi$ - the heat flux; $E_{(T)}-$ calorimetric sensitivity; $T_{S}-$ the measured sample temperature; $T_{\text {set }}$ - the temperature value, which is set by the temperature program [16].

Processing of the results and plotting are performed using Microsoft Office Excel 2007 software.

The adequacy of the regression equation is carried out by checking the statistical significance of the coefficient of determination $R^{2}$ by the $F$-criterion determined by the formula [17]:

$$
F_{p}=\frac{R^{2}}{1-R^{2}} \cdot \frac{n-m-1}{m},
$$

where $n$ - the number of observations; $m$ - the number of factors in the regression equation.

\section{Research results}

Thermophysical properties of polymer compositions that are filled to 60 mass \% of aluminum oxide trihydrate, magnesium oxide dihydrate, hydromagnesites is evaluated by differential scanning calorimetry. The content of the modifier in the compositions is varied from 0 to $0.8 \%$ by mass.

The phase transition temperatures are determined from characteristic points of the description of physical phenomena in the DSC diagrams. Examples of DSC diagrams are shown in Fig. 1, 2.

The beginning of the melting effect (Fig. 1) is defined as the point of intersection of the baseline with the diagram before the phase transition. The end of the effects is defined as the intersection point of the baseline with the diagram after the phase transition and the tangent curve drawn to the inflection point.

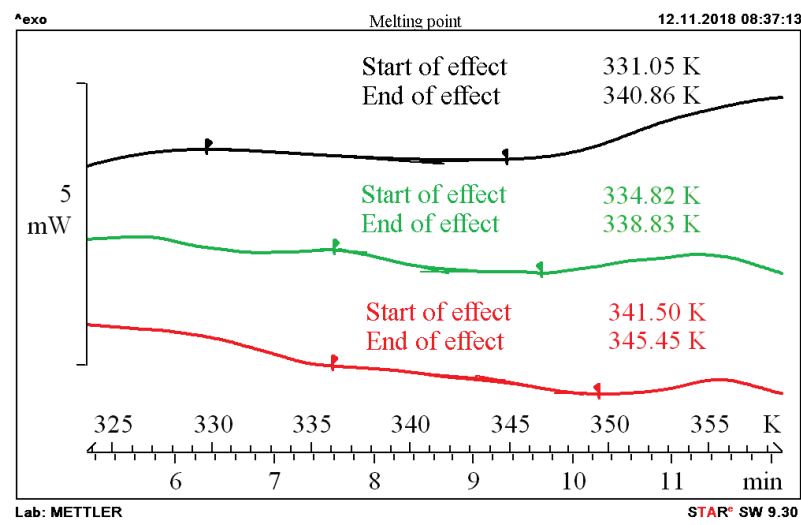

Fig. 1. $\mathrm{DSC}$ diagram. Melting point: — - EVA; — - EVA+60 \% filler-flame retardant (sample 1); — - EVA+60 \% filler-flame retardant (sample 1)+0.8\% modifier 


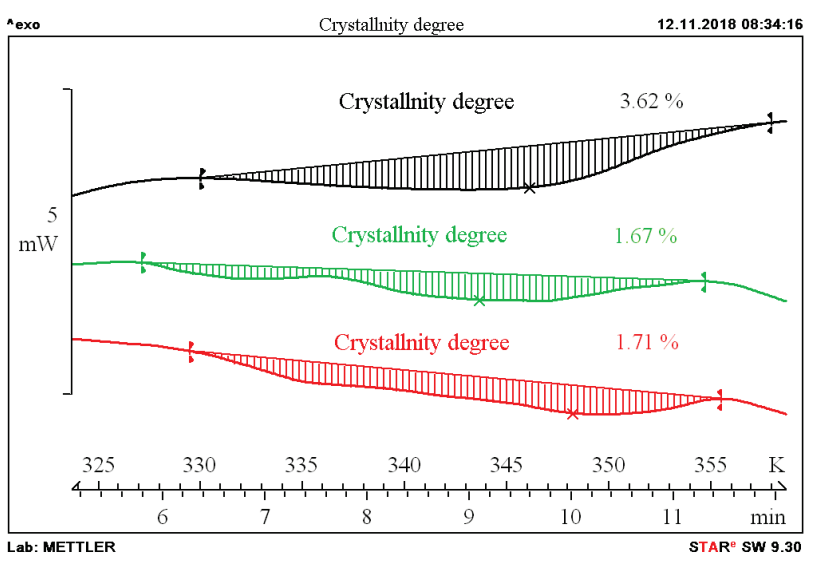

Fig. 2. DSC diagram. Crystallinity degree: - - EVA;

EVA+60 \% filler-flame retardant (sample 1); — - EVA+60\% filler-flame retardant (sample 1)+0.8\% modifier

The crystallinity degree $(C)$ (Fig. 2) is calculated by the formula:

$$
C=\frac{\Delta H}{\Delta H_{100 \%}} \cdot 100 \%,
$$

where $C$ - crystallinity of the material, $\% ; \Delta H$ - experimental heat of melting, $\mathrm{J} / \mathrm{g} ; \Delta H_{100 \%}$ - the heat of fusion of the material with $100 \%$ crystallinity, $\mathrm{J} / \mathrm{h}$.

Specific heat is calculated by the formula:

$$
\Delta C_{p}=\frac{\dot{H}}{\beta \cdot m},
$$

where $\Delta C_{p}$ - the specific heat, $\mathrm{J} / \mathrm{g} \cdot \mathrm{K} ; \beta$ - heating rate, $\mathrm{K} / \mathrm{min}$; $m$ - mass; $\dot{H}$ - enthalpy, $\mathrm{J} / \mathrm{mol}$ (defined as the shortest distance between two horizontal lines drawn through the start and end points of the effect).

According to the obtained values, let's plot graphs of the melting point, the crystallinity degree, the mass loss, and the specific heat capacity of the polymer compositions on their composition. The results are shown in Fig. 3-5.

Temperature determination of the decomposition of polymer compositions is carried out using DSC diagrams obtained using a TGA/DSC instrument 1/1100 SF (temperature rise rate -10 degree $/ \mathrm{min}$ ).

Temperatures of the beginning and end of the decomposition were defined as the intersection points of the baseline with the diagram before and after the decomposition of polymer compositions and the tangent to the diagram drawn to the inflection point (Fig. 6).

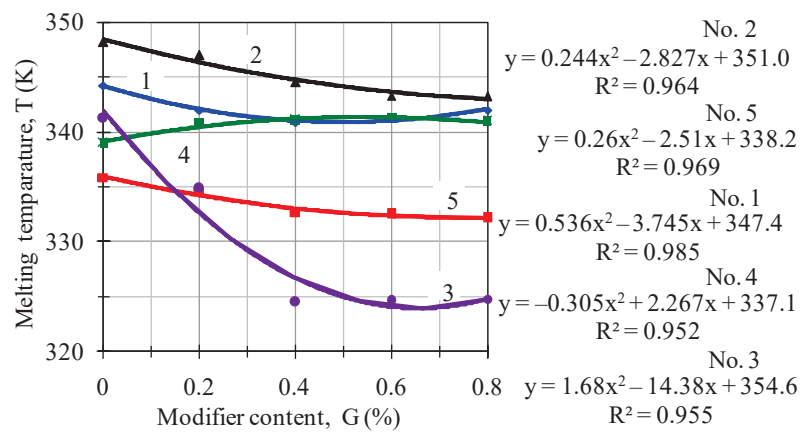

Fig. 3. Dependence of the melting point on the content of the modifier and fillers-flame retardants (sample 1-5)

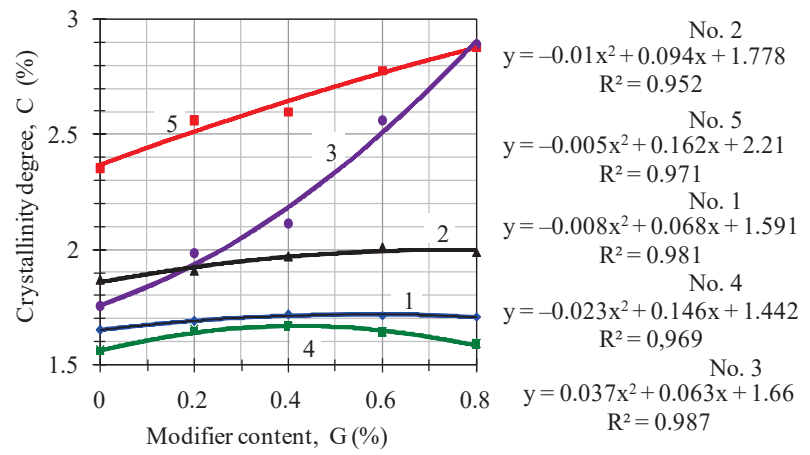

Fig. 4. Dependence of the crystallinity degree on the content of the modifier and fillers-flame retardants (sample 1-5)

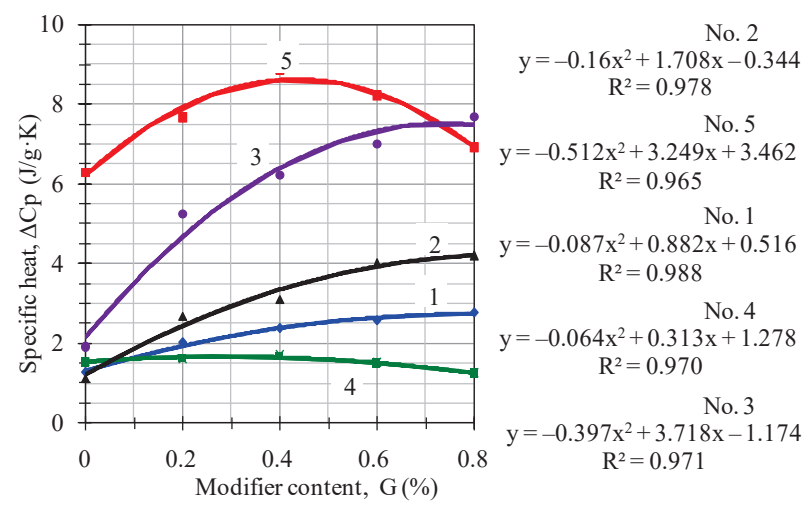

Fig. 5. Dependence of the specific heat on the content of the modifier and fillers-flame retardants (sample 1-5)

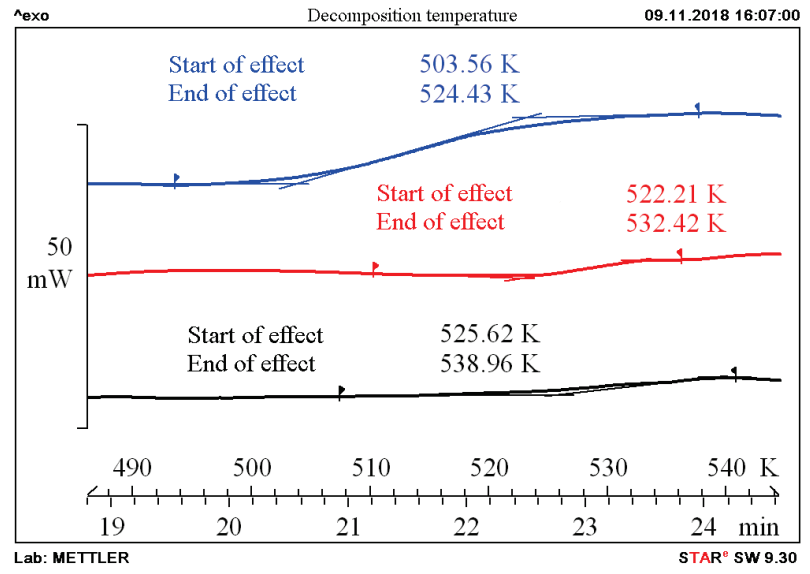

Fig. 6. D5C diagram. Decomposition begin and end temperatures: - EVA; — - EVA+60 \% filler-flame retardant (sample 4); - EVA+60 \% filler-flame retardant (sample 4)+0.8\% modifier

Using the obtained data, let's plot temperature dependences of the decomposition beginning due to endothermic reactions depending on their composition. The results are shown in Fig. 7.

The next stage of the research is determination of the influence of the polymer compositions' ingredients depending on the mass loss of the polymer compositions during thermal decomposition at a temperature of $723 \mathrm{~K}$. The TGA curves at $293 \mathrm{~K}$ to $723 \mathrm{~K}$, heating rates of $10 \mathrm{deg} / \mathrm{min}$ are shown in Fig. 8.

Fig. 8 presents TGA diagrams for EVA, EVA, which is filled with fire retardant and a modifier is introduced. 
Such TGA diagrams are recorded for polymer compositions with various flame retardant fillers, as well as with flame retardant fillers with different modifier content. The mass loss is determined by the distance on the ordinate axis between the tangent to the TGA diagram and parallel to the abscissa axis at the end of the process. According to the obtained values of the mass loss, this indicator depended on the content of the modifier. The results of TG analyzes for all polymer compositions are shown in Fig. 9.

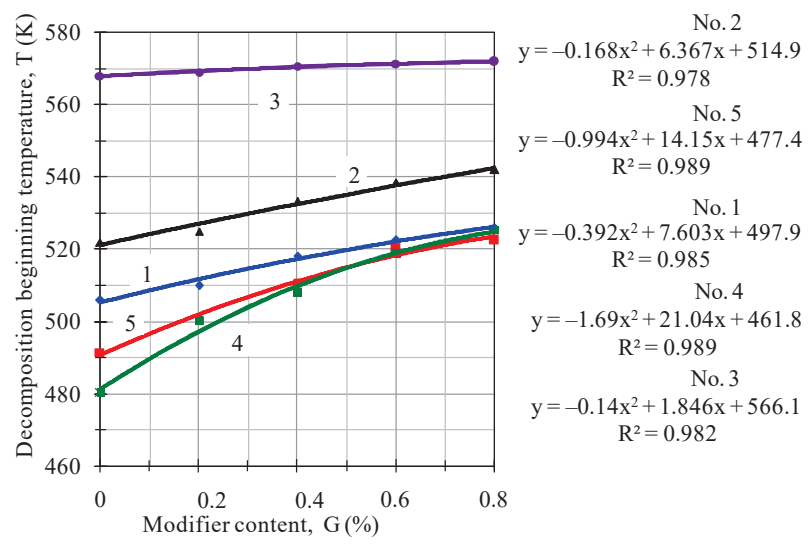

Fig. 7. Dependence of the decomposition beginning temperature on the content of the modifier and fillers-flame retardants (sample 1-5)

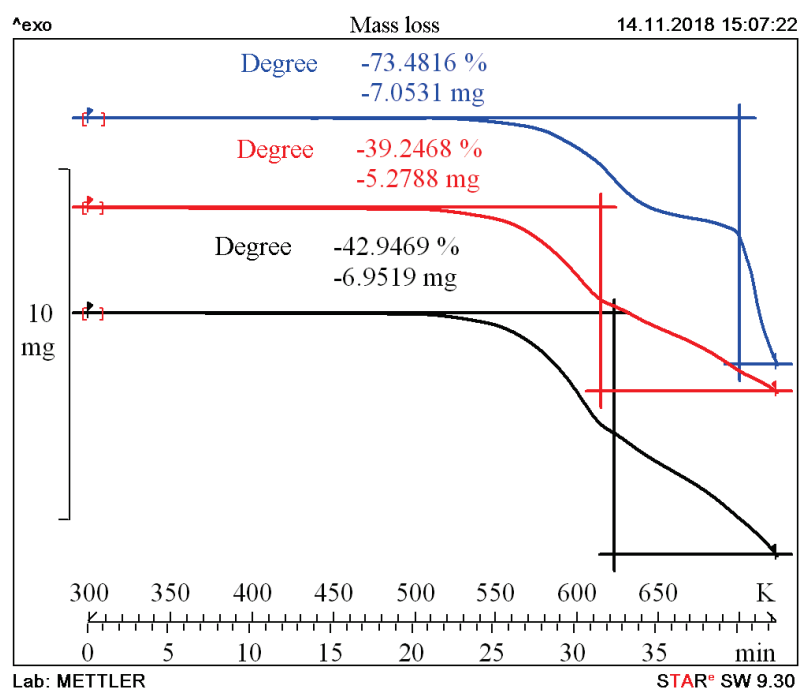

Fig. 8. TGA diagram. Mass loss: —— EVA; - - EVA+60 \% filler-flame retardant (sample 1); — - EVA+60 \% filler-flame retardant (sample 1)+0.8\% modifier

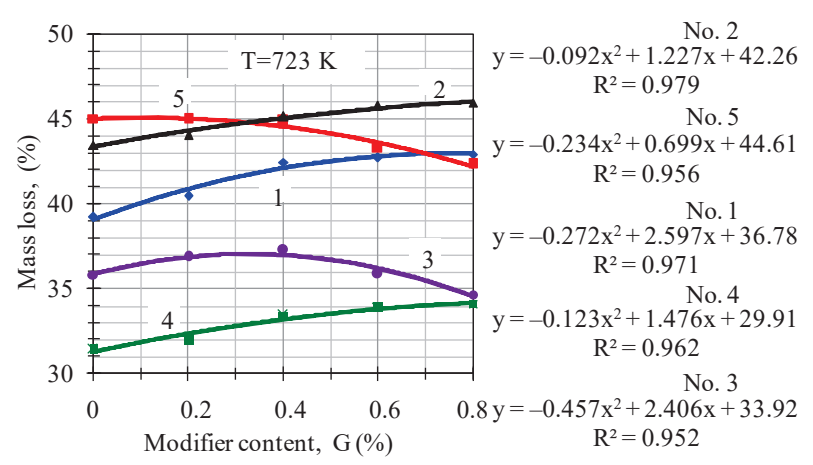

Fig. 9. The dependence of mass loss on the content of the modifier and fillers-flame retardants (sample 1-5)
The temperature of phase transitions (melting point), as well as the crystallinity degree and specific heat of polymer compositions is studied by the DSC method. The dependence of these indicators on the properties of the ingredients and the amount of the polymer composition modifier (Fig. 1-6) shows that the melting points (Fig. 4) decrease with increasing content of the modifier for all samples. Melting points of polymer compositions that are filled with:

- aluminum oxide trihydrate reduced by $2.3-4.6$ degrees;

- dihydrate of magnesium oxide - by 1.2-16.2 degrees;

- hydromagnesites - by 3.7 degrees.

The melting point is significantly reduced when using fillers with a large average particle diameter.

The crystallinity degree (Fig. 6) increases with increasing content of the polymer composition modifier. A particularly sharp increase in the crystallinity degree is observed in compositions using magnesium oxide dihydrate with a large average particle diameter and hydromagnesite.

The specific heat of all polymer compositions (Fig. 6) increases with an increase in the amount of modifier. This indicator has the highest values when using hydromagnesite (sample 5) and magnesium oxide dihydrate with a smaller average particle diameter (sample 3).

It should be noted that the important parameters during the operation of the compositions is the temperature of the decomposition beginning, since it characterizes the initial stage of destruction during combustion.

An analysis of the DSC curves (Fig. 6) makes it possible to reveal exothermic effects in the temperature range from $490 \mathrm{~K}$ to $540 \mathrm{~K}$ for polymer compositions with different modifier content.

Analysis of the results shows that the temperature of the decomposition beginning increases for all polymer compositions in which the modifier is introduced.

For polymer compositions that are filled with aluminum trihydrate, this figure increases by 20 degrees; for magnesium oxide dihydrate - by (3-45) degrees; for hydromagnesite - by 31 degrees.

As can be seen from the dependences obtained for polymer compositions with aluminum oxide trihydrate, the mass loss increases from $1.06 \%$ to $3.7 \%$ with an increase in the amount of modifier. Moreover, with an increase in the dispersity of the filler-flame retardant, the mass loss decreases (sample 2).

For polymer compositions with magnesium oxide dihydrate, the increase in mass loss is from $1.04 \%$ to $8.5 \%$. For a filler with a smaller average particle diameter (sample 3), an increase in mass loss of $1.04 \%$ passes through a maximum in a modifier content of $0.4 \%$.

For polymer compositions with hydromagnesites, the mass loss is reduced by $6.3 \%$ with an increase in the content of the modifier.

The obtained results can be explained by the various physicochemical, thermophysical properties of the components of the polymer compositions.

An important influence on the thermophysical properties of the investigated compositions is the formation of the supramolecular structure of the obtained compositions. This is evidenced by the research results of phase transformations, the crystallinity degree and specific heat capacity. 


\section{SWOT analysis of research results}

Strengths. The obtained results allow to reduce the processing temperature and expand the processing window by lowering the melting temperature, increasing the decomposition temperature, increasing the crystallinity degree, increasing the specific heat with increasing content of the polymer composition modifier.

Weaknesses. The ingredients of polymer compositions must be imported because they are not produced in Ukraine.

Opportunities. The results will be useful in the development of fireproof polymer formulations for cable products and directional control of thermal properties during their processing.

Threats. It is necessary to master the technological process of manufacturing, personnel training in the management of the technological process.

\section{Conclusions}

1. It is proved that the melting point of fireproof compositions depends on the content of the modifier and decreases with an increase in its concentration by $1.2-16.2$ degrees. A significant decrease in the melting point is observed when using alumina trihydrate and hydromagnesite. The crystallinity degree and specific heat capacity of all polymer compositions increases with increasing content of the modifier.

2. It is shown that the temperatures of the decomposition beginning increase from 20 to 45 degrees with an increase in the amount of the modifier and the properties of the ingredients of the polymer compositions. There is a slight increase in the weight loss of the polymer compositions:

- with alumina trihydrate from $1.06 \%$ to $3.7 \%$;

- with dihydrate of magnesium oxide from $1.04 \%$ to $8.5 \%$;

- with hydromagnesites, the mass loss decreases by $6.3 \%$ with an increase in the content of the modifier.

Thus, studies have shown the possibility of regulating fireproof polymer compositions using a modifier and fillersfire retardants of different qualitative composition and dispersion.

\section{References}

1. Peshkov I. B. Materialy kabel'nogo proizvodstva. Moscow: Mashinostroenie, 2013. $456 \mathrm{p}$

2. Chulieieva O. Development of directed regulation of rheological properties of fire retardant composite materials of ethylene vinyl acetate copolymer // Technology Audit and Production Reserves. 2017. Vol. 2, Issue 1 (40). P. 25-31. doi: http:// doi.org/10.15587/2312-8372.2018.129699

3. Tirelli D. Antipireny dlya kompozitov // The Chemical Journal. 2013. Issue 1-2. P. 42-45.

4. Obzor mineral'nykh antipirenov-gidroksidov dlya bezgalogennykh kabel'nykh kompozitsiy // Kabel'-news. 2009. Issue 8. P. 41-43.
5. Ableev R. Aktual'nye problemy v razrabotke i proizvodstve negoryuchikh polimernykh kompaundov dlya kabel'noy industrii // Kabel'-news. 2009. Issue 6-7. P. 64-69.

6. Mechanical and fire retardant properties of EVA/clay/ATH nanocomposites - Effect of particle size and surface treatment of ATH filler / Cárdenas M. A. et. al. // Polymer Degradation and Stability. 2008. Vol. 93, Issue 11. P. 2032-2037. doi: http://doi.org/10.1016/j.polymdegradstab.2008.02.015

7. Calcium-based hydrated minerals: Promising halogen-free flame retardant and fire resistant additives for polyethylene and ethylene vinyl acetate copolymers / Laoutid F. et. al. // Polymer Degradation and Stability. 2013. Vol. 98, Issue 9. P. 1617-1625. doi: http://doi.org/10.1016/j.polymdegradstab.2013.06.020

8. Effect of Amino alcohol functionalized polyethylene as compatibilizer for LDPE/EVA/clay/flame-retardant nanocomposites / Lujan-Acosta R. et. al. // Materials Chemistry and Physics. 2014. Vol. 146, Issue 3. P. 437-445. doi: http://doi.org/10.1016/ j.matchemphys.2014.03.050

9. Thermal study of low-grade magnesium hydroxide used as fire retardant and in passive fire protection / Formosa J. et. al. // Thermochimica Acta. 2011. Vol. 515, Issue 1-2. P. 43-50. doi: http://doi.org/10.1016/j.tca.2010.12.018

10. Fire retardant benefits of combining aluminum hydroxide and silica in ethylene-vinyl acetate copolymer (EVA) / Sonnier R. et. al. // Polymer Degradation and Stability. 2016 Vol. 128. P. 228-236. doi: http://doi.org/10.1016/j.polymdegradstab.2016.03.030

11. Chang M.-K., Hwang S.-S., Liu S.-P. Flame retardancy and thermal stability of ethylene-vinyl acetate copolymer nanocomposites with alumina trihydrate and montmorillonite // Journal of Industrial and Engineering Chemistry. 2014. Vol. 20, Issue 4 P. 1596-1601. doi: http://doi.org/10.1016/j.jiec.2013.08.004

12. Jeencham R., Suppakarn N., Jarukumjorn K. Effect of flame retardants on flame retardant, mechanical, and thermal properties of sisal fiber/polypropylene composites // Composites Part B: Engineering. 2014. Vol. 56. P. 249-253. doi: http:// doi.org/10.1016/j.compositesb.2013.08.012

13. Chemical modification of henequén fibers with an organosilane coupling agent / Valadez-Gonzalez A. et. al. // Composites Part B: Engineering. 1999. Vol. 30, Issue 3. P. 321-331. doi: http://doi.org/10.1016/s1359-8368(98)00055-9

14. Effect of N-2-(aminoethyl)-3-aminopropyltrimethoxysilane surface modification and C.I. Acid Red 18 dye adsorption on the physicochemical properties of silica precipitated in an emulsion route, used as a pigment and a filler in acrylic paints / Jesionowski T. et. al. // Dyes and Pigments. 2003. Vol. 57, Issue 1. 29-41. doi: http://doi.org/10.1016/s0143-7208(03)00006-8

15. Juvaste H., Iiskola E. I., Pakkanen T. T. Aminosilane as a coupling agent for cyclopentadienyl ligands on silica // Journal of Organometallic Chemistry. 1999. Vol. 587, Issue 1. P. 38-45. doi: http://doi.org/10.1016/s0022-328x(99)00264-8

16. $\mathrm{STAR}^{\mathrm{e}}$ thermal analysis system, operating instructions to the TGA/DSC1. Switzerland: Mettler Toledo AG, 2007.

17. Makarova N. V., Trofimets V. Ya. Statistika v Excel: textbook. Moscow: Finansy i statistika, 2002. 368 p.

Chulieieva Olena, PhD, Director of the Center, Scientific and Technical Center, PJSC «Yuzhcable Works», Kharkiv, Ukraine, e-mail: echuleeva@ukr.net,ORCID: http://orcid.org/0000-0002-7310-0788

Zolotaryov Volodymyr, Doctor of Technical Sciences, Professor, General Director, PJSC «Yuzhcable Works», Kharkiv, Ukraine, e-mail: zavod@yuzhcable.com.ua, ORCID: http://orcid.org/00000002-3886-4993 